\title{
Comparison of longitudinal treatment effects with facemask and chincup therapy followed by fixed orthodontic treatment on Class III malocclusion
}

\author{
Nam-Ki Lee, DDS, MSD, ${ }^{a}$ Seung-Hak Baek DDS, MSD, $\mathrm{PhD}^{\mathbf{b}}$
}

\begin{abstract}
Objective: The purpose of this study was to compare the longitudinal treatment effects of facemask with rapid maxillary expansion (FM/RME) and chincup (CC) therapy followed by fixed orthodontic treatment (FOT) in Class III malocclusion (CIII) patients. Methods: The samples consisted of twenty-one CIII patients who had similar skeletal and dental characteristics before FM/RME or CC therapy and good retention results (Class I molar/canine relationship and positive overbite/overjet) after FOT (Group 1, FM/RME, $\mathrm{n}=$ 11; Group 2, CC, $n=10$ ). Lateral cephalograms were taken before (TO) and after FM/RME or CC therapy (T1), and after FOT and retention (T2). Skeletal and dental variables were measured. Mann-Whitney U-test and Wilcoxon signed-rank test were used for statistical analysis. Results: During T0-T1, FM/RME therapy induced forward movement of point $\mathrm{A}$, and labioversion of the upper incisors. Both groups showed posterior repositioning of the mandible. FM/RME resulted in increase of the vertical dimension; however, CC caused an increase in articular angle and decrease in gonial angle. During T1-T2, both groups exhibited forward growth of point A. Group 1 showed forward growth and counterclockwise rotation of the mandible and increase of IMPA; however, Group 2, showed increase of ANS-Me/N-Me and decrease of overbite. Conclusions: The key factor for successful FM/RME and CC therapy and good retention results might be a harmonized forward growth of the maxilla that could keep pace with the growth and rotation of the mandible. (Korean J Orthod 2009;39(6):362-371)
\end{abstract}

Key words: Class III malocclusion, Facemask, Chin cup, Longitudinal evaluation

\section{INTRODUCTION}

Skeletal Class III malocclusion occurs because of an undergrowth of the maxilla, an overgrowth of the mandible, or both. ${ }^{1-5}$ Orthopedic treatment has been used to

${ }^{a}$ Graduate Student, ${ }^{b}$ Associate Professor, Department of Orthodontics, School of Dentistry, Seoul National University.

Corresponding author: Seung-Hak Baek.

Department of Orthodontics, School of Dentistry, Dental Research Institute, Seoul National University, 28, Yeongeon-dong, Jongno-gu, Seoul 110-768, Korea

+82 2072 3952; e-mail,drwhite@unitel.co.kr.

Received May 14, 2009; Last Revision September 24, 2009;

Accepted September 28, 2009

DOl:10.4041/kjod.2009.39.6.362 prevent the skeletal problems associated with this condition from becoming more severe, to eliminate or reduce the need for orthognathic surgery, and to improve the psychosocial well-being and appearance of the patient. $^{6-8}$

Facemask with rapid maxillary expansion (FM/ $\mathrm{RME}$ ) or chin cup (CC) therapy has been used to treat growing patients with skeletal Class III malocclusion based on the cause of the skeletal discrepancy. Previous studies that have investigated the effects of FM/ RME have reported forward movement of point A, counterclockwise rotation of the palatal plane, extrusion of the upper molars, labioversion of the maxillary incisors, and eventual clockwise rotation of the 
mandible. ${ }^{4,8-18}$ However, CC therapy has been shown to induce clockwise rotation and/or distal displacement of the mandible, to redirect mandibular growth vertically, and to remodel the mandible with closure of the gonial angle. $^{16,19-24}$

Although several studies have evaluated the longterm craniofacial changes that occur as a result of using either of these orthopedic approaches, $4,8,16,20,23-28$ there have been few studies to date that have directly compared treatment effects between FM/RME and CC therapy. ${ }^{29}$ To precisely compare the treatment effects of these appliances, a confined set of patients that have both similar skeletal and dental patterns prior to orthopedic treatment and good retention results after fixed orthodontic treatment are necessary. Therefore, the purpose of this retrospective study was to compare the longitudinal treatment effects of FM/RME and CC therapy followed by comprehensive fixed orthodontic treatment in patients with skeletal Class III maloc- clusion.

\section{MATERIAL AND METHODS}

The samples consisted of twenty-one patients with Class III malocclusion who had similar skeletal and dental patterns, were treated by Delaire type FM/RME or Occipital pull $\mathrm{CC}$, and exhibited good retention results after comprehensive fixed orthodontic treatment (approximately 5 years after the end of FM/RME or CC therapy). The criteria for good retention results consisted of a Class I canine and molar relationship, positive overbite and overjet, and a pleasing facial profile.

The patients were allocated into Group 1 (FM/RME, $\mathrm{n}=11,6$ girls and 5 boys; mean age $=10.4 \pm 1.5$ years) and Group 2 (CC, $\mathrm{n}=10,5$ girls and 5 boys; mean age $=9.9 \pm 1.0$ years) based on the treatment method they received. For both groups, the orthopedic

Table 1. Definition of the variables

\begin{tabular}{|c|c|c|}
\hline \multicolumn{2}{|c|}{ Variables } & Definition \\
\hline \multirow{7}{*}{$\begin{array}{l}\text { Anteroposterior } \\
\text { relationship }\end{array}$} & SNA $\left({ }^{\circ}\right)$ & The angle between the anterior cranial base $(\mathrm{SN})$ and NA line \\
\hline & $\mathrm{A}-\mathrm{N}$ perp $(\mathrm{mm})$ & $\begin{array}{l}\text { The perpendicular distance from A to the Nasion perpendicular line to the } \\
\text { FH plane }\end{array}$ \\
\hline & $\mathrm{SNB}\left({ }^{\circ}\right)$ & The angle between the anterior cranial base $(\mathrm{SN})$ and $\mathrm{NB}$ line \\
\hline & Pog - N perp (mm) & $\begin{array}{l}\text { The perpendicular distance from Pog to the Nasion perpendicular line to the } \\
\text { FH pane }\end{array}$ \\
\hline & $\mathrm{ANB}\left({ }^{\circ}\right)$ & The angle between NA and NB lines \\
\hline & APDI $\left({ }^{\circ}\right)$ & $\begin{array}{l}\text { Anteroposterior dysplasia indicator, The sum of facial plane (N-Pog) to } \mathrm{FH} \\
\text { plane angle, } \mathrm{AB} \text { to facial plane angle, and palatal plane (ANS-PNS) to } \mathrm{FH} \\
\text { plane angle }\end{array}$ \\
\hline & OJ (mm) & Overjet \\
\hline \multirow{8}{*}{$\begin{array}{l}\text { Vertical } \\
\text { relationship }\end{array}$} & $\mathrm{SN}-\mathrm{GoGn}\left({ }^{\circ}\right)$ & The angle between SN plane and Go-Gn line \\
\hline & $\mathrm{OB}(\mathrm{mm})$ & Overbite \\
\hline & ODI $\left({ }^{\circ}\right)$ & $\begin{array}{l}\text { Overbite depth indicator, The sum of } \mathrm{AB} \text { to mandibular plane angle and } \\
\text { palatal plane (ANS-PNS) to } \mathrm{FH} \text { plane angle }\end{array}$ \\
\hline & $\mathrm{S}-\mathrm{Go} / \mathrm{N}-\mathrm{Me}(\%)$ & Posterior facial height $(\mathrm{S}-\mathrm{Go}) /$ Anterior facial height $(\mathrm{N}-\mathrm{Me}) * 100$ \\
\hline & ANS-Me/N-Me (\%) & $\begin{array}{l}\text { Lower anterior facial height }(\mathrm{ANS}-\mathrm{Me}) \text { / Anterior facial height }(\mathrm{N}-\mathrm{Me}) \text { * } \\
100\end{array}$ \\
\hline & Articular angle $\left(^{\circ}\right)$ & The angle between $\mathrm{S}-\mathrm{Ar}$ line and $\mathrm{Ar}-\mathrm{Go}$ line \\
\hline & Gonial angle $\left(^{\circ}\right)$ & The angle between $\mathrm{Gn}-\mathrm{Go}$ line and $\mathrm{Go}^{-} \mathrm{Ar}$ line \\
\hline & Björk sum $\left({ }^{\circ}\right)$ & The sum of saddle angle, articular angle, and gonial angle \\
\hline \multirow{3}{*}{$\begin{array}{l}\text { Dental } \\
\text { relationship }\end{array}$} & $\mathrm{U} 1$ to $\mathrm{SN}\left({ }^{\circ}\right)$ & The angle between maxillary incisor axis line and $\mathrm{SN}$ plane \\
\hline & $\operatorname{IMPA}\left({ }^{\circ}\right)$ & The angle between mandibular incisor axis line and mandibular plane \\
\hline & Interincisal angle $\left(^{\circ}\right)$ & The angle between upper and lower incisor axis lines \\
\hline
\end{tabular}


appliances were used for at least 12 to 14 hours per day with a force of 300 to $500 \mathrm{~g}$ per side. After a 2 to $3 \mathrm{~mm}$ overbite and overjet was obtained, all subjects were treated with a straight archwire appliance (MBT set-up, 0.022" slot, 3M-Unitek, Monrovia, CA, USA). During that period the orthopedic treatment was not accompanied. In Group 1, eight patients were treated with nonextraction and three with premolar extraction, while in Group 2, five were treated with nonextraction and five with premolar extraction. Fixed lingual retainers and removable circumferential retainers were also used.

Lateral cephalograms with centric occlusion, reposed lip, and natural head position were taken before (T0) and after FM/RME or CC therapy (T1), and after fixed orthodontic treatment and retention (T2). The cephalometric variables are listed in Table 1. Cephalometric tracing and measurements were performed by one investigator using a digitizer (Intuos2 graphic tablet, Wacom Technology Co, Vancouver, Canada) and VCeph software (CyberMed, Seoul, Korea) at units of 0.05 degrees and $0.05 \mathrm{~mm}$. Five randomly selected sets of cephalograms were retraced and redigitized after 2 weeks to determine the level of error in the initial measurements. There was no significant difference between the measurements (Dahlberg's formula, error of the linear measurement $<0.94 \mathrm{~mm}$; error of the angular measurement $<1.05^{\circ}$ ), and thus the initial measurements were used for this study.

For statistical analysis, the program SPSS for Windows version 14 (SPSS Inc., Chicago, IL, USA) was used. Wilcoxon signed rank test was used to determine the difference between $\mathrm{T} 0$ and $\mathrm{T} 1$ stages and between
T1 and T2 stages within the same group. Mann-Whitney test was used to compare the differences between Groups 1 and 2 during orthopedic therapy (T0-T1) and fixed orthodontic treatment and retention (T1-T2).

\section{RESULTS}

Comparison of the mean age according to the stage between Groups 1 and 2 (Table 2)

There was no significant difference in age at each stage between Groups 1 and 2, indicating that the samples were matched in terms of age. The mean durations of the orthopedic treatment with the FM/RME and $\mathrm{CC}$ therapies were 1.4 and 2.0 years, respectively. The mean durations of the fixed orthodontic treatment and retention for Groups 1 and 2 were 5.1 and 5.2 years, respectively.

Comparison of the skeletal and dental variables prior to FM/RME and CC therapy between Groups 1 and 2 (Table 3)

There was no significant difference in the skeletal and dental variables at T0 stage between Groups 1 and 2 except interincisal angle (larger in Group $1, p<$ 0.05). These findings imply that the samples were well matched in terms of their skeletal and dental variables.

Table 2. Comparison of the mean age according to the different stages between Groups 1 and 2

\begin{tabular}{|c|c|c|c|c|c|}
\hline \multirow[t]{2}{*}{ Stage } & \multicolumn{2}{|c|}{$\begin{array}{c}\text { Group } 1 \\
(\mathrm{FM} / \mathrm{RME}, \mathrm{n}=11)\end{array}$} & \multicolumn{2}{|c|}{$\begin{array}{c}\text { Group } 2 \\
(\mathrm{CC}, \mathrm{n}=10)\end{array}$} & \multirow[t]{2}{*}{ Significance } \\
\hline & Mean & $\mathrm{SD}$ & Mean & $\mathrm{SD}$ & \\
\hline T0 (years) & 10.4 & 1.5 & 9.9 & 1.0 & 0.139 \\
\hline T1 (years) & 11.8 & 1.3 & 11.9 & 0.9 & 0.916 \\
\hline T2 (years) & 16.9 & 1.3 & 17.1 & 1.0 & 0.778 \\
\hline
\end{tabular}

Mann-Whitney test was done. FM/RME means facemask with rapid maxillary expansion; CC, chincup; T0, before FM/RME or CC treatment; T1, after FM/RME or CC treatment; T2, after fixed orthodontic treatment and retention; $\mathrm{SD}$, standard deviation; NS, not significant $(p>0.05)$. 
Table 3. Comparison of the anteroposterior, vertical and dental variables between Groups 1 and 2

\begin{tabular}{|c|c|c|c|c|c|c|}
\hline & \multirow[t]{2}{*}{ T0 stage } & \multicolumn{2}{|c|}{$\begin{array}{c}\text { Group } 1 \\
(\mathrm{FM} / \mathrm{RME}, \mathrm{n}=11)\end{array}$} & \multicolumn{2}{|c|}{$\begin{array}{c}\text { Group } 2 \\
(\mathrm{CC}, \mathrm{n}=10)\end{array}$} & \multirow[t]{2}{*}{ Significance } \\
\hline & & Mean & $\mathrm{SD}$ & Mean & $\mathrm{SD}$ & \\
\hline \multirow{7}{*}{$\begin{array}{l}\text { Anteroposterior } \\
\text { relationship }\end{array}$} & SNA $\left({ }^{\circ}\right)$ & 79.45 & 2.81 & 78.56 & 2.53 & 0.56 \\
\hline & A to $\mathrm{N}$ perp $(\mathrm{mm})$ & -2.65 & 4.65 & -2.82 & 2.17 & 0.35 \\
\hline & $\operatorname{SNB}\left({ }^{\circ}\right)$ & 80.65 & 3.09 & 79.48 & 2.70 & 0.28 \\
\hline & Pog to $\mathrm{N}$ perp (mm) & -2.33 & 8.91 & -3.34 & 3.96 & 0.31 \\
\hline & $\mathrm{ANB}\left({ }^{\circ}\right)$ & -1.18 & 2.19 & -0.99 & 1.45 & 0.76 \\
\hline & APDI $\left({ }^{\circ}\right)$ & 89.17 & 2.77 & 90.42 & 3.22 & 0.35 \\
\hline & Overjet $(\mathrm{mm})$ & -1.81 & 2.13 & -2.02 & 0.89 & 0.34 \\
\hline \multirow[t]{8}{*}{ Vertical relationship } & $\mathrm{SN}-\mathrm{GoGn}\left({ }^{\circ}\right)$ & 36.67 & 4.65 & 35.58 & 4.07 & 0.56 \\
\hline & Overbite $(\mathrm{mm})$ & 3.60 & 3.26 & 2.08 & 2.15 & 0.25 \\
\hline & ODI $\left(^{\circ}\right)$ & 63.09 & 5.23 & 64.04 & 4.02 & 0.61 \\
\hline & $\mathrm{S}-\mathrm{Go} / \mathrm{N}-\mathrm{Me} \quad(\%)$ & 63.19 & 3.18 & 63.55 & 2.86 & 0.76 \\
\hline & ANS-Me/N-Me (\%) & 54.10 & 1.34 & 54.19 & 1.50 & 0.81 \\
\hline & Articular angle $\left(^{\circ}\right)$ & 148.47 & 5.56 & 147.88 & 3.50 & 0.92 \\
\hline & Gonial angle $\left(^{\circ}\right)$ & 126.49 & 5.58 & 122.79 & 4.75 & 0.15 \\
\hline & Björk sum $\left({ }^{\circ}\right)$ & 396.69 & 4.60 & 395.75 & 4.09 & 0.61 \\
\hline \multirow[t]{3}{*}{ Dental relationship } & $\mathrm{U} 1-\mathrm{SN}\left({ }^{\circ}\right)$ & 102.08 & 6.34 & 106.09 & 5.11 & 0.20 \\
\hline & $\operatorname{IMPA}\left({ }^{\circ}\right)$ & 83.52 & 6.20 & 84.65 & 4.10 & 0.61 \\
\hline & Inter-incisal angle $\left(^{\circ}\right)$ & 137.73 & 10.42 & 126.55 & 6.26 & $0.02^{*}$ \\
\hline
\end{tabular}

Mann-Whitney test was done. FM/RME means facemask with rapid maxillary expansion; CC, chin cup; T0, before $\mathrm{FM} / \mathrm{RME}$ or CC treatment; SD, standard deviation; ${ }^{*} p<0.05$.

Comparison of the skeletal and dental changes during FM/RME and CC therapy in each group (Table 4)

In the anteroposterior position of the maxilla, there was significant forward movement in Group 1 (A to $\mathrm{N}$ perp, $p<0.05$ ), but not in Group 2, as expected. In the anteroposterior position of the mandible, both groups exhibited significant posterior repositioning of the mandible (SNB, $p<0.01$; Pog to $\mathrm{N}$ perp, $p<$ 0.01 ; APDI, $p<0.01$; ANB, $p<0.01$, both respectively). In addition, Group 1 showed a more significant improvement in overjet $(p<0.01)$ due to labioversion of the upper incisors $(p<0.01)$.

Regarding changes in the vertical relationship, there was a significant increase of SN-GoGn $(p<0.01)$, ANS-Me/N-Me $(p<0.01)$, and Björk sum $(p<$ $0.01)$, as well as decrease of overbite $(p<0.05)$ in Group 1, and a significant increase in articular angle $(p<0.05)$ and decrease in gonial angle $(p<0.01)$ in Group 2.

There was a significant decrease in interincisal angle $(p<0.05)$ due to significant labioversion of the upper incisors in Group $1(p<0.01)$; however, there were no significant changes in inclination of the lower incisors of Group 1, nor the upper and lower incisors of Group 2.

Comparison of changes in the skeletal and dental variables during FM/RME and CC therapy between Groups 1 and 2 (Table 4)

There was no significant difference in the amount of change in the anteroposterior positions of the maxilla and the mandible between Groups 1 and 2; however, Group 1 did exhibit a significant increase in overjet compared to Group $2(p<0.05)$.

Regarding changes in the vertical relationship, there were significant differences in the amount of change in ANS-Me/N-Me $(p<0.01)$, SN-GoGn $(p<0.05)$, 
Table 4. Comparison of changes in the anteroposterior, vertical and dental variables during FM/RME and CC therapy in each group and between groups

\begin{tabular}{|c|c|c|c|c|c|c|c|c|c|c|c|}
\hline & & Group & $1(\mathrm{FM} /$ & ME, $r$ & $=11)$ & Grc & up 2 & $\mathrm{C}, \mathrm{n}=$ & & & \\
\hline & 11 & Median & Mean & $\mathrm{SD}$ & Sig* $^{*}$ & Median & Mean & SD & Sig $^{*}$ & & \\
\hline Anteroposterior & SNA $\left({ }^{\circ}\right)$ & 1.10 & 0.95 & 1.40 & 0.062 & 0.75 & 0.53 & 1.48 & 0.241 & 0.480 & 0.507 \\
\hline relationship & A to $\mathrm{N}$ perp (mm) & 1.70 & 1.15 & 1.66 & $0.041^{\dagger}$ & 0.50 & 0.47 & 1.38 & 0.260 & 0.359 & 0.320 \\
\hline & $\mathrm{SNB}\left({ }^{\circ}\right)$ & -2.30 & -2.26 & 1.12 & $0.003^{\ddagger}$ & -1.85 & -2.03 & 1.21 & $0.005^{\ddagger}$ & 0.417 & 0.652 \\
\hline & Pog to $\mathrm{N}$ perp (mm) & -4.50 & -3.98 & 2.98 & $0.008^{\ddagger}$ & -3.60 & -3.89 & 1.97 & $0.005^{\ddagger}$ & 0.698 & 0.953 \\
\hline & $\mathrm{ANB}\left({ }^{\circ}\right)$ & 3.30 & 3.20 & 1.75 & $0.003^{\ddagger}$ & 2.75 & 2.60 & 1.08 & $0.005^{\ddagger}$ & 0.438 & 0.362 \\
\hline & APDI $\left({ }^{\circ}\right)$ & -7.60 & -8.27 & 4.93 & $0.004^{\ddagger}$ & -5.75 & -5.28 & 1.92 & $0.005^{\ddagger}$ & 0.130 & 0.085 \\
\hline & Overjet (mm) & 7.30 & 7.49 & 2.58 & $0.003^{\ddagger}$ & 5.20 & 4.90 & 1.45 & 0.284 & $0.015^{\dagger}$ & $0.011^{\dagger}$ \\
\hline Vertical & SN-GoGn $\left({ }^{\circ}\right)$ & 2.00 & 2.43 & 1.89 & $0.003^{\ddagger}$ & 0.75 & 0.44 & 1.34 & 0.308 & $0.020^{\dagger}$ & $0.013^{\dagger}$ \\
\hline relationship & Overbite (mm) & -2.10 & -2.65 & 2.89 & $0.016^{\dagger}$ & -1.30 & -0.53 & 2.45 & 0.441 & 0.113 & 0.087 \\
\hline & ODI $\left({ }^{\circ}\right)$ & 5.00 & 3.72 & 3.21 & $0.010^{\dagger}$ & 6.40 & 6.04 & 2.33 & $0.005^{\ddagger}$ & 0.132 & 0.076 \\
\hline & $\mathrm{S}-\mathrm{Go} / \mathrm{N}-\mathrm{Me}(\%)$ & -1.20 & -1.06 & 1.75 & 0.075 & 0.25 & 0.39 & 1.27 & 0.475 & 0.067 & 0.054 \\
\hline & ANS-Me/N-Me (\%) & 1.40 & 1.58 & 1.30 & $0.003^{\ddagger}$ & -0.10 & -0.23 & 1.22 & 0.720 & $0.003^{\ddagger}$ & $0.004^{\ddagger}$ \\
\hline & Articular angle $\left(^{\circ}\right)$ & 2.40 & 2.72 & 4.25 & 0.061 & 3.40 & 3.11 & 2.36 & $0.012^{\dagger}$ & 0.622 & 0.800 \\
\hline & Gonial angle $\left({ }^{\circ}\right)$ & 0.00 & -0.70 & 2.17 & 0.263 & -3.00 & -2.93 & 2.03 & $0.007^{\ddagger}$ & $0.037^{\dagger}$ & $0.025^{\dagger}$ \\
\hline & Björk sum $\left(^{\circ}\right)$ & 2.10 & 2.45 & 1.92 & $0.003^{\ddagger}$ & 0.70 & 0.49 & 1.39 & 0.284 & $0.018^{\dagger}$ & $0.016^{\dagger}$ \\
\hline Dental & $\mathrm{U} 1-\mathrm{SN}\left({ }^{\circ}\right)$ & 5.30 & 7.05 & 6.67 & $0.003^{\ddagger}$ & 4.30 & 3.64 & 7.54 & 0.086 & 0.468 & 0.285 \\
\hline relationship & $\operatorname{IMPA}\left({ }^{\circ}\right)$ & -0.70 & -1.58 & 4.13 & 0.213 & -1.60 & -2.08 & 4.50 & 0.241 & 0.944 & 0.794 \\
\hline & Inter-incisal angle $\left({ }^{\circ}\right)$ & -7.30 & -7.50 & 9.23 & $0.008^{\dagger}$ & -3.25 & -3.08 & 11.95 & 0.285 & 0.078 & 0.352 \\
\hline
\end{tabular}

Wilcoxon signed rank test was done. ${ }^{*}$ Means comparison between T0 and T1 stages within the same group. ${ }^{\dagger} p<$ $0.05 ;{ }^{\ddagger} p<0.01$. Mann-Whitney test was done. ${ }^{\S}$ Means comparison of changes during FM/RME and CC therapy (T0-T1) between Group 1 and Group 2; ${ }^{\dagger} p<0.05 ;{ }^{\dagger} p<0.01$. Median test was done. " Means comparison of changes during FM/RME and CC therapy (T0-T1) between Group 1 and Group $2 ;{ }^{\dagger} p<0.05 ;{ }^{\dagger} p<0.01$.

Björk sum $(p<0.05)$, and gonial angle $(p<0.05)$ between Groups 1 and 2. These findings suggest that FM/RME and CC therapy may exert different effects on the vertical dimension in cases with successful results.

There were no significant differences in the amount of change of the dental variables between Groups 1 and 2 .

Comparison of changes in the skeletal and dental variables during fixed orthodontic treatment and retention in each group (Table 5)

For the anteroposterior position of the maxilla and the mandible, both groups showed significant forward growth of point $\mathrm{A}$ (A to $\mathrm{N}$ perp, $p<0.05$, respectively). Although both groups revealed statistically significant deterioration of overjet $(p<0.01$ in Group $1, p<0.05$ in Group 2), significant forward repositioning and growth of the mandible (Pog to $\mathrm{N}$ perp, $p<0.01$ ) was observed in Group 1 only.

In the vertical relationship, there was a significant counterclockwise rotation of the mandible (decrease of SN-GoGn and Björk sum, $p<0.05$, respectively) in Group 1; however, Group 2 had a significantly increased lower anterior facial height (ANS-Me/N-Me, $p$ $<0.01)$ and decreased overbite $(p<0.05)$. These findings indicate that there may be a different tendency of change in vertical dimension between Groups 1 and 2 during T1-T2 phase.

In Group 1, although there was no significant change in inclination of the upper incisors, the lower incisors were significantly labially inclined (IMPA, $p$ $<0.05)$. There was no difference in inclination of the 
Table 5. Comparison of changes in the anteroposterior, vertical and dental variables during fixed orthodontic treatment and retention in each group and between groups

\begin{tabular}{|c|c|c|c|c|c|c|c|c|c|c|c|}
\hline & \multirow{2}{*}{$\mathrm{T} 2-\mathrm{T} 1$} & \multicolumn{4}{|c|}{ Group $1(\mathrm{FM} / \mathrm{RME}, \mathrm{n}=11)$} & \multicolumn{4}{|c|}{ Group $2(\mathrm{CC}, \mathrm{n}=10)$} & \multirow{2}{*}{$\operatorname{Sig}^{\S}$} & \multirow{2}{*}{ Sig $"$} \\
\hline & & Median & Mean & $\mathrm{SD}$ & Sig $^{*}$ & Median & Mean & $\mathrm{SD}$ & Sig $^{*}$ & & \\
\hline \multirow{7}{*}{$\begin{array}{l}\text { Anteroposterior } \\
\text { relationship }\end{array}$} & SNA $\left({ }^{\circ}\right)$ & 1.10 & 0.75 & 1.60 & 0.248 & 1.40 & 0.98 & 1.35 & 0.058 & 0.481 & 0.732 \\
\hline & A to $\mathrm{N}$ perp (mm) & 0.70 & 1.47 & 2.01 & $0.046^{\dagger}$ & 0.95 & 0.88 & 0.92 & $0.022^{\dagger}$ & 0.672 & 0.393 \\
\hline & $\mathrm{SNB}\left({ }^{\circ}\right)$ & 0.50 & 0.99 & 1.56 & 0.091 & 1.05 & 1.19 & 2.01 & 0.097 & 0.916 & 0.801 \\
\hline & Pog to N perp (mm) & 5.20 & 4.43 & 3.69 & $0.008^{\ddagger}$ & 1.95 & 2.77 & 4.68 & 0.093 & 0.324 & 0.377 \\
\hline & $\mathrm{ANB}\left({ }^{\circ}\right)$ & -0.10 & -0.24 & 1.87 & 0.878 & -0.25 & -0.22 & 2.04 & 0.721 & 0.725 & 0.985 \\
\hline & APDI $\left({ }^{\circ}\right)$ & 1.50 & 2.18 & 3.74 & 0.102 & 0.80 & 1.45 & 4.98 & 0.358 & 0.778 & 0.706 \\
\hline & Overjet (mm) & -2.30 & -2.65 & 2.78 & $0.007^{\dagger}$ & -1.00 & -0.80 & 0.85 & $0.032^{\dagger}$ & 0.113 & 0.058 \\
\hline \multirow{8}{*}{$\begin{array}{l}\text { Vertical } \\
\text { relationship }\end{array}$} & SN-GoGn $\left({ }^{\circ}\right)$ & -1.80 & -1.74 & 1.45 & $0.012^{\dagger}$ & -1.45 & -1.74 & 2.97 & 0.114 & 0.918 & 0.997 \\
\hline & Overbite (mm) & 0.80 & 0.55 & 2.26 & 0.508 & -1.00 & -1.08 & 0.88 & $0.011^{\dagger}$ & 0.084 & 0.054 \\
\hline & ODI $\left({ }^{\circ}\right)$ & 2.10 & 0.86 & 4.23 & 0.328 & 0.45 & 0.21 & 3.18 & 0.646 & 0.549 & 0.366 \\
\hline & $\mathrm{S}-\mathrm{Go} / \mathrm{N}-\mathrm{Me}(\%)$ & 1.30 & 0.76 & 3.05 & 0.161 & 2.90 & 2.92 & 2.78 & $0.017^{\dagger}$ & 0.113 & 0.108 \\
\hline & ANS-Me/N-Me (\%) & 0.00 & -0.23 & 1.45 & 0.635 & 1.05 & 1.09 & 0.84 & $0.007^{\dagger}$ & $0.029^{\dagger}$ & $0.021^{\dagger}$ \\
\hline & Articular angle $\left({ }^{\circ}\right)$ & 0.40 & 0.22 & 3.76 & 0.722 & -1.35 & -0.57 & 4.74 & 0.610 & 0.622 & 0.676 \\
\hline & Gonial angle $\left(^{\circ}\right)$ & -1.90 & -1.32 & 2.99 & 0.203 & -0.60 & -1.43 & 2.30 & 0.092 & 0.888 & 0.925 \\
\hline & Björk sum $\left({ }^{\circ}\right)$ & -1.70 & -1.65 & 1.41 & $0.010^{\dagger}$ & -1.35 & -1.75 & 2.93 & 0.114 & 0.833 & 0.920 \\
\hline \multirow{3}{*}{$\begin{array}{l}\text { Dental } \\
\text { relationship }\end{array}$} & $\mathrm{U} 1-\mathrm{SN}\left({ }^{\circ}\right)$ & -2.50 & -1.85 & 5.83 & 0.213 & 1.20 & 1.01 & 4.81 & 0.386 & 0.307 & 0.237 \\
\hline & $\operatorname{IMPA}\left({ }^{\circ}\right)$ & 7.80 & 5.67 & 4.70 & $0.011^{\dagger}$ & 0.40 & 0.92 & 5.16 & 0.799 & $0.035^{\dagger}$ & $0.040^{\dagger}$ \\
\hline & Inter-incisal angle $\left(^{\circ}\right)$ & -0.50 & -2.50 & 8.36 & 0.959 & -1.25 & -3.05 & 7.37 & 0.386 & 0.805 & 0.875 \\
\hline
\end{tabular}

Wilcoxon signed rank test was done. ${ }^{*}$ Means comparison between T1 and T2 stages within the same group. ${ }^{\dagger} p<$ $0.05 ;{ }^{\ddagger} p<0.01$. Mann-Whitney test was done. ${ }^{\S}$ Means comparison of changes during fixed orthodontic treatment and retention (T1-T2) between Group 1 and Group $2 ;{ }^{\dagger} p<0.05$. Median test was done. " Means comparison of changes during fixed orthodontic treatment and retention (T1-T2) and CC therapy (T0-T1) between Group 1 and Group 2; ${ }^{\dagger} p<0.05$.

upper and lower incisors for Group 2.

Comparison of changes in the skeletal and dental variables during fixed orthodontic treatment and retention between Groups 1 and 2 (Table 5)

There was no significant difference in the amount of change in the anteroposterior position of point $\mathrm{A}$ and the mandible between Groups 1 and 2. In the vertical relationship, Group 2 exhibited a significant increase in ANS-Me/N-Me $(p<0.05)$ compared to Group 1, while Group 1 exhibited a significant increase in IMPA $(p<0.05)$ compared to Group 2.

\section{DISCUSSION}

Skeletal and dental variables before FM/ RME and CC therapy (TO)

Results of the orthopedic and orthodontic treatments, as well as growth of the maxilla and mandible, can be affected by original skeletal and dental characteristics. $^{22,24,30}$ In this study, at T0 stage, there were no significant differences in the anteroposterior position and vertical dimension of the maxilla and mandible between Groups 1 and 2 (Table 3). Therefore, both groups appeared to have similar skeletal characteristics for Class III malocclusion prior to orthopedic treatment.

FM/RME group had a greater interincisal angle ( $p$ $<0.05$, Table 3 ) because of a greater lingual in- 
clination tendency of the upper incisor than CC group, although this difference was not statistically significant. Since Class III malocclusion patients with severe compensated upper and lower incisors, vertical growth pattern, and prognathic mandible would be one of the contraindication of $\mathrm{FM} / \mathrm{RME}$ and $\mathrm{CC}$ therapy, these types of patients were excluded from initial sampling. Uçüncü et al. ${ }^{29}$ reported that there were significant differences in the position of the upper incisor between FM/RME and CC groups at T0 stage. In this study, lingual inclination of the upper incisors with retruded maxilla could be a good indicator for determining FM/ $\mathrm{RME}$ therapy or CC therapy.

Changes in the skeletal and dental variables during FM/RME and CC therapy (TO-T1)

Regarding the amount of change in the anteroposterior position of the maxilla, there was a significant forward movement of the maxilla (A to $\mathrm{N}$ perp, $p<$ 0.05 , Table 4) in FM/RME group, which was expected based on the results of previous studies. ${ }^{4,8,9,12,16,31,32} \mathrm{CC}$ group did not show a significant forward movement of the maxilla (Table 4), which was also in accordance with other studies; ${ }^{19,21,33,34}$ however, the finding that there was no significant difference in the amount of change of point $\mathrm{A}$ between groups 1 and 2 during T0-T1 (Table 4) indicates that forward growth of the maxilla could have occurred after correction of the anterior crossbite in CC group, although the extent to which this occurred was less than FM/RME group. Also no significant difference in the amount of change of point $A$ between Groups 1 and 2 may be due to the difference of treatment duration between groups 1 and 2 .

In the present study, both FM/RME and CC groups showed significant improvement in their sagittal skeletal discrepancy (SNB, Pog to N perp, ANB, APDI; $p$ $<0.01$, Table 4), which was consistent with other studies. $^{5,8,9,12,14,16,25,29,35}$ In addition, FM/RME therapy induced more significant improvement of overjet $(p<$ 0.05, Table 4) compared to CC group during T0-T1, which was attributed to significant forward movement of the maxilla and labioversion of the upper incisors of FM/RME group (A to $\mathrm{N}$ perp, $p<0.05$; U1-SN, $p$ $<0.01$; Table 4).
With respect to the vertical relationship, FM/RME group exhibited more significant clockwise rotation of the mandible than did $\mathrm{CC}$ group (SN-GoGn, Björk sum, ANS-Me/N-Me, $p<0.01$, Table 4). These findings indicate that FM/RME caused a significant increase in vertical dimension, while $\mathrm{CC}$ might have had a remodeling effect on the mandible. Consistent with this finding, Uçüncü et al. ${ }^{29}$ and Arman et al. ${ }^{16}$ reported that there was significant clockwise rotation of the mandible during FM therapy.

Although CC therapy is known to cause significant clockwise rotation of the mandible, ${ }^{19-23} \mathrm{CC}$ group in this study, which had good orthopedic treatment results, did not exhibit the same outcome, which is in accordance with Ko et al., ${ }^{24}$ who, after performing a long term study of CC therapy, reported that the group with poorest retention results showed more clockwise rotation than the group with good retention results. Mitani and Sakamoto ${ }^{36}$ insisted that retardation of the forward growth of the chin during chincup treatment was dependent upon a reduction of the growth increment of mandibular length and a decrease in gonial angle in addition to distal displacement of the mandible. Therefore, a decrease in gonial angle $(p<0.01$, Table 4 ), labioversion of the upper incisor, and linguoversion of the lower incisors could all have contributed to increase of overjet observed with CC therapy in this study.

The finding that both groups had the same tendency for labioversion of the upper incisor and linguoversion of the lower incisor (Table 4) was also consistent with previous studies. ${ }^{5,10,21,25,26,33}$

Changes in the skeletal and dental variables after fixed orthodontic treatment and retention (T1-T2)

With respect to the forward growth of the maxilla and mandible in Class III malocclusion patients after orthopedic treatment, previous studies have shown that, after FM/RME therapy, the maxilla grows the same as untreated Class III malocclusion patients, but less than Class I malocclusion patients, and that the amount of mandibular growth was similar among these groups. ${ }^{13,15,27}$ Wisth et al. ${ }^{37}$ reported that changes of the maxilla and 
mandible in patients treated with FM and quad-helix were not significantly different from Class I malocclusion controls.

Numerous studies ${ }^{19,20,25,36}$ have reported that catch-up growth of the mandible in the forward direction after $\mathrm{CC}$ therapy resulted in return to the original skeletal morphology and growth pattern. However, Deguchi et al. $^{23}$ insisted that changes in the sagittal maxillary and mandibular relationship by $\mathrm{CC}$ therapy remained stable after fixed orthodontic treatment and retention. Ko et $\mathrm{al}^{24}$ reported on the basis of a long term study of Class III malocclusion patients with CC therapy, that patients with the poor retention results had more counterclockwise rotation and forward growth of the mandible compared with patients who had good retention results.

When compared to the changes in point $\mathrm{A}$ to $\mathrm{N}$ perp with Pog to $\mathrm{N}$ perp between Groups 1 and 2 (1.47 $\mathrm{mm}$ vs $4.43 \mathrm{~mm}$ and $0.88 \mathrm{~mm}$ vs $2.77 \mathrm{~mm}$, respectively, Table 5), the net differences were $2.96 \mathrm{~mm}$ and $1.89 \mathrm{~mm}$, respectively. This finding suggests that although the skeletal characteristics of Class III malocclusion might recur to a certain degree during T1-T2, there was significant forward growth of the maxilla in both groups ( $p<0.05$, respectively, Table 5). Considering the chronological age of the patients at the T2 stage, there was likely very little remaining mandibular growth potential, especially in girls. To evaluate the end of active skeletal growth, the skeletal age such as hand-wrist and cervical vertebral maturation index method would be needed.

The finding of a significant decrease in SN-GoGn and Björk sum in Group $1(p<0.05$, respectively, Table 5) and increase in S-Go/N-Me in Group $2(p<$ 0.05 , Table 5) indicates that the mandible rotated counterclockwise due to relapse and continued growth of the mandible. In addition, Group 2 exhibited a significantly increase of lower facial height ratio (ANS$\mathrm{Me} / \mathrm{N}-\mathrm{Me}, p<0.01$, Table 5), which was in accordance with the findings of $\mathrm{Ko}$ et $\mathrm{al}^{24}$

The significantly decreased overjet in Group $1(p<$ 0.01 , Table 5) appeared to be due to the significant labioversion of the lower incisors $(p<0.05$, Table 5) and counterclockwise rotation and growth of the mandible (SN-GoGn, Björk sum, $p<0.05$, respectively,
Table 5).

There are some limitations of this study such as small sample size, sexual dimorphism of subjects, use of the chronological age, and need of untreated Class III or Class I malocclusion as control groups.

\section{CONCLUSION}

1. FM/RME and CC therapy produced a different spectrum of effects on skeletal and dental components.

2. The key factor for successful FM/RME and CC therapy and good retention results might be a harmonized forward growth of the maxilla that could keep pace with the growth and rotation of the mandible.

- 국문초록 -

상악전방견인장치와 이모장치 및 고정식 교정장치 치료를 받은 $I I I$ 급 부정교합 환자의

치료효과에 대한 종단적 비교

$$
\text { 이남기 }{ }^{a} \cdot \text { 백승학 }
$$

본 연구는 상악전방견인장치 또는 이모장치 치료 후 고정 식 교정장치로 치료 받은 III급 부정교합 환자의 치료효과에 대한 종단적 비교를 위해 시행되었다. 상악전방견인 치료 또 는 이모장치 치료 전의 골격 및 치아 유형이 유사하며 고정 식 교정치료 후 좋은 유지결과(I급 구치/견치 관계 및 양의 수직/수평피개)를 보이는 21명의 환자(1군, 상악전방견인장 치, 11명; 2군, 이모장치, 10명)를 대상으로 하였다. 상악전 방견인 치료 또는 이모장치 치료 전(T0)과 후(T1), 고정식 교 정치료 후 유지기간(T2)에 측모두부방사선사진을 촬영하여 골격 및 치아에 대한 계측치를 이용하였다. 통계적 분석을 위해 비모수 검정법(Mann-Whitney U-test and Wilcoxon signed-rank test)을 이용하였다. 악정형 치료 시기(T0-T1)에, 1 군에서는 상악골의 전방 이동 (point $\mathrm{A}, p<0.05$ ), 상악 전 치의 순측경사 $(p<0.01)$ 및 수평피개의 증가 $(p<0.01)$ 가 보였다. 하악골은 1군과 2군 모두에서 후방 위치를 보였 다 (SNB, Pog-N perp, ANB, $p<0.01$ ). 1군에서는 수직고 경의 증가 $(\mathrm{SN}-\mathrm{GoGn}, \mathrm{ANS}-\mathrm{Me} / \mathrm{N}-\mathrm{Me}$, Björk sum, $p<$ $0.01)$ 가 나타난 반면에, 2 군에서는 articular angle의 증가 ( $p$ $<0.05)$ 와 gonial angle의 감소 $(p<0.01)$ 가 보였다. 고정 식 교정치료 및 유지기간(T1-T2)에, 1군과 2군 모두는 상악 골의 전방성장 (point $\mathrm{A}, p<0.05$ )을 보였다. 한편 1 군은 하 
악골의 전방성장 (Pog-N perp, $p<0.01)$ 및 반시계방향 회 전 (SN- GoGn, Björk sum, $p<0.05$ )과 하악 전치의 순측 경사 (IMPA, $p<0.05$ )를 나타냈으며, 2군은 ANS-Me/ $\mathrm{N}-\mathrm{Me}$ 의 증가 $(p<0.01)$ 와 수직피개의 감소 $(p<0.05)$ 를 보였다. 비록 상악전방견인 치료와 이모장치 치료의 골격 및 치성적 효과가 서로 차이가 있을지라도, 이 두 치료법으로 인한 결과가 장기간 안정적으로 유지되기 위해서 하악골의 회전 및 성장에 맞추어 상악골의 지속적인 전방성장이 필요 한 것으로 생각된다.

주요 단어: |||급 부정교합, 상악전방견인장치, 이모장치, 종 단적 연구

\section{REFERENCES}

1. Campbell PM. The dilemma of Class III treatment. Early or late? Angle Orthod 1983;53:175-91.

2. Guyer EC, Ellis EE 3rd, McNamara JA Jr, Behrents RG. Components of class III malocclusion in juveniles and adolescents. Angle Orthod 1986;56:7-30.

3. McNamara JA. An orthopedic approach to the treatment of Class III malocclusion in young patients. J Clin Orthod 1987; 21:598-608.

4. Ngan PW, Hagg U, Yiu C, Wei SH. Treatment response and long-term dentofacial adaptations to maxillary expansion and protraction. Semin Orthod 1997;3:255-64.

5. Park HC, Lee JW. Study of horizontal skeletal pattern and dental arch in skeletal Class III malocclusion patients. Korean J Orthod 2008;38:358-69.

6. Turley PK. Orthopedic correction of Class III malocclusion with palatal expansion and custom protraction headgear. J Clin Orthod 1988;22:314-25.

7. Turley PK. Orthopedic correction of Class III malocclusion: retention and phase II therapy. J Clin Orthod 1996;30:313-24.

8. Arman A, Ufuk Toygar T, Abuhijleh E. Evaluation of maxillary protraction and fixed appliance therapy in Class III patients. Eur J Orthod 2006;28:383-92.

9. Baik HS. Clinical results of the maxillary protraction in Korean children. Am J Orthod Dentofacial Orthop 1995;108: 583-92.

10. Chong YH, Ive JC, Artun J. Changes following the use of protraction headgear for early correction of Class III malocclusion. Angle Orthod 1996;66:351-62.

11. Shanker S, Ngan P, Wade D, Beck M, Yiu C, Hägg U, et al. Cephalometric A point changes during and after maxillary protraction and expansion. Am J Orthod Dentofacial Orthop 1996;110:423-30

12. Kapust AJ, Sinclair PM, Turley PK. Cephalometric effects of face mask/expansion therapy in Class III children: a comparison of three age groups. Am J Orthod Dentofacial Orthop 1998;113:204-12.

13. Gallagher RW, Miranda F, Buschang PH. Maxillary protraction: treatment and posttreatment effects. Am J Orthod Dentofacial Orthop 1998;113:612-9.
14. Sung SJ, Baik HS. Assessment of skeletal and dental changes by maxillary protraction. Am J Orthod Dentofacial Orthop 1998;114:492-502.

15. Macdonald KE, Kapust AJ, Turley PK. Cephalometric changes after the correction of Class III malocclusion with maxillary expansion/facemask therapy. Am J Orthod Dentofacial Orthop 1999;116:13-24.

16. Arman A, Toygar TU, Abuhijleh E. Profile changes associated with different orthopedic treatment approaches in Class III malocclusions. Angle Orthod 2004;74:733-40.

17. Kama JD, Ozer T, Baran S. Orthodontic and orthopedic changes associated with treatment in subjects with Class III malocclusions. Eur J Orthod 2006;28:496-502.

18. Tortop T, Keykubat A, Yuksel S. Facemask therapy with and without expansion. Am J Orthod Dentofacial Orthop 2007;132: 467-74.

19. Sakamoto T, Iwase I, Uka A, Nakamura S. A roentgenocephalometric study of skeletal changes during and after chin cup treatment. Am J Orthod 1984;85:341-50.

20. Sugawara J, Asano T, Endo N, Mitani H. Long-term effects of chincap therapy on skeletal profile in mandibular prognathism. Am J Orthod Dentofacial Orthop 1990;98:127-33.

21. Allen RA, Connolly IH, Richardson A. Early treatment of Class III incisor relationship using the chincap appliance. Eur J Orthod 1993;15:371-6.

22. Ishikawa $\mathrm{H}$, Nakamura $\mathrm{S}$, Kim $\mathrm{C}$, Iwasaki $\mathrm{H}$, Satoh $\mathrm{Y}$, Yoshida S. Individual growth in Class III malocclusions and its relationship to the chin cap effects. Am J Orthod Dentofacial Orthop 1998;114:337-46.

23. Deguchi T, Kuroda T, Minoshima Y, Graber TM. Craniofacial features of patients with Class III abnormalities: growth-related changes and effects of short-term and long-term chincup therapy. Am J Orthod Dentofacial Orthop 2002;121:84-92.

24. Ko YI, Baek SH, Mah J, Yang WS. Determinants of successful chincup therapy in skeletal Class III malocclusion. Am J Orthod Dentofacial Orthop 2004;126:33-41.

25. Uner $\mathrm{O}$, Yüksel $\mathrm{S}$, Uçüncü $\mathrm{N}$. Long-term evaluation after chincap treatment. Eur J Orthod. 1995;17:135-41.

26. Ngan P, Yiu C, Hu A, Hägg U, Wei SH, Gunel E. Cephalometric and occlusal changes following maxillary expansion and protraction. Eur J Orthod 1998;20:237-54.

27. Westwood PV, McNamara JA Jr, Baccetti T, Franchi L, Sarver DM. Long-term effects of Class III treatment with rapid maxillary expansion and facemask therapy followed by fixed appliances. Am J Orthod Dentofacial Orthop 2003;123:306-20.

28. Pangrazio-Kulbersh V, Berger JL, Janisse FN, Bayirli B. Long-term stability of Class III treatment: rapid palatal expansion and protraction facemask vs LeFort I maxillary advancement osteotomy. Am J Orthod Dentofacial Orthop 2007; 131:7.e9-19.

29. Uçüncü N, Uçem TT, Yüksel S. A comparison of chincap and maxillary protraction appliances in the treatment of skeletal Class III malocclusions. Eur J Orthod 2000;22:43-51.

30. Hwang CJ, Moon JL. A retrospective study on profile having favorable response to Facemask. Korean J Orthod 1999;29: 147-56.

31. Mermigos J, Full CA, Andreasen G. Protraction of the maxillofacial complex. Am J Orthod Dentofacial Orthop 1990;98: 
47-55

32. Merwin D, Ngan P, Hagg U, Yiu C, Wei SH. Timing for effective application of anteriorly directed orthopedic force to the maxilla. Am J Orthod Dentofacial Orthop 1997;112:292-9.

33. Ritucci R, Nanda R. The effect of chin cup therapy on the growth and development of the cranial base and midface. Am J Orthod Dentofacial Orthop 1986;90:475-83.

34. Hwang CI, Suhr CH. A roentgenocephalometric study on the effects of the chincap in the skeletal Class III malocclusion.
Korean J Orthod 1989;19:219-44.

35. Chen KF, So LL. Sagittal skeletal and dental changes of reverse headgear treatment in Chinese boys with complete unilateral cleft lip and palate. Angle Orthod 1996;66:363-72.

36. Mitani H, Sakamoto T. Chin cap force to a growing mandible. Long-term clinical reports. Angle Orthod 1984;54:93-122.

37. Wisth PJ, Tritrapunt A, Rygh P, Bøe OE, Norderval K. The effect of maxillary protraction on front occlusion and facial morphology. Acta Odontol Scand 1987;45:227-37. 